\title{
Use of ICT/Web Tools in ELT in Nepal
}

\author{
Chandra Prasad Acharya
}

\begin{abstract}
Information and Communication Technology (ICT) has become an integral part of English Language Teaching (ELT) to meet the needs of the present day world. It has brought significant changes in the traditional teacher-centered lecturing methods. However, this emerging field of study has not been researched rigorously in the context of Nepal. Considering this, the research study carried out at the Department of English Education, Tribhuvan University, Kathmandu aimed to find out the commonly used ICT/Web tools in ELT and its positive impact on ELT practice. The sample size of the study consisted of 40 English teachers of private Secondary and Higher Secondary Schools of Kathmandu Valley. The informants were selected using judgmental non-random sampling from Kathmandu, Lalitpur and Bhaktapur districts in a proportionate way. A questionnaire consisting of both closeended and open-ended questions was used as a data collection tool. The data were analyzed and interpreted descriptively and statistically. The result of the data obtained revealed that the ICT tools such as mobile phone, laptop, multimedia projector and web tools like YouTube, Facebook, wiki, email, blog are used in ELT and have positive impact on ELT.
\end{abstract}

Key Words: ICT, Impact on ELT, Classroom Practice, Effectiveness in ELT, Digital Divide

\section{Background}

English is a 'West Germanic' language that was first spoken in England and is now the most widely used language all around the world. It is one of the richest languages since it has its wide coverage, rich vocabulary, written literature and high population of its users. Approximately 375 million people speak English as their first language.Since English has its worldwide coverage, teaching English takes place all around the world. It is one of the major languages taught in schools and universities. English Language Teaching (ELT) is an area that is in change over the years, moving from very teacher-centered lecturing approaches to learner-centered ones. More recently, the use of technology as a tool to develop the different language skills has received great attention so that English language teachers are frequently exposed to new practices to carry out better ELT classroom activities today. The use of technological devices such as televisions, computers, tape recorders and video recorders have been incorporated as a tool for language teaching since 1960s when Computer-assisted Language Learning started.

Teaching English in the era of science and technology is being very much challenging because of the innovation in different theories, methods, principles and the influence of Information and 
Communication Technology (ICT). As everything is in the process of change, the ELT in the world is also in the process of change. The ELT scenario today is quite different than some years back. This is because of the change process. To this, a language teacher should be well equipped with the knowledge to cope with the media world and should be updated with the digital world and should adopt ICT tools in his job to make his profession comfortable and for the betterment of his learners.

\section{Rationale of the study}

As the phrase 'Technology in Education' has become the buzz word in every educational atmosphere in the world, Nepalese ELT is no exception. It has become a very important part of the educational delivery and management processes. It is becoming increasingly important in both our personal and professional lives. The Information and Communication Technologies are now an integral part of language teaching. There are glaring disparities between different countries and different regions within the same countries. These differences are quite serious and problematic, and we must do our best to eliminate them because they block learners' access to knowledge and skills. It is the technology which would help them to participate more actively and meaningfully. Thus, the integration of technology in ELT helps create opportunities to learners.

This research seeks to address some major concerns in the current practice of Information and Communication Technology and Web Tools in English Language Teaching in Nepalese Private Secondary and Higher Secondary educational settings. In particular, it seeks to address the tension between the ICTintegrated ELT setting and lecturedominated context till date.

Thus, I have undertaken this study to explore possibilities of using ICT/Web tools which teachers could integrate into their classrooms teaching. The study can also offer a strong foundation of technical and instructional support that teachers could gradually become more comfortable with the idea of integrating technology into their instruction on a regular basis. The following were the objectives of the study:

To identify the commonly used ICT/Web Tools in ELT.

- To find out the uses of ICT/Web Tools in carrying out effective ELT activities.

- To recommend some pedagogical implications based on the research findings.

\section{Theoretical premises and research overview}

\section{ICT and English language teaching}

ICT is defined as a diverse set of technological tools and resources used to communicate, and to create, disseminate, store and manage information. The breakthrough of Information and Communication Technologies has utterly shaped our personal and professional lives. The United Nations Development Programme (UNDP) (2003) defines ICT as follows:

Basically information-handling toolsa varied set of goods, applications and services that are used to produce, store, process, distribute and exchange information. They include the 'old' ICTs of radio, television and telephone, and the 'new' ICTs of computers, satellite and wireless technology and the Internet. These different tools are now able to work together, and combine to form our 'networked world', a massive infrastructure of interconnected telephone services, standardized 
computing hardware, the internet, radio and television, which reaches into every corner of the globe.

ICT has been around in language teaching for decades. Computer-based materials for language teaching, often referred as CALL (Computer Assisted Language Learning) appeared in the early 1980s including the activities like CDs, teaching computer programs, computer test, and encyclopedias. Similarly, in the 1990s the term TELL (Technology Enhanced Language Learning) was in practice in response to the growing possibilities offered by the Internet. And, today computers and the Internet allows language teachers and learners to connect, collaborate and communicate online throughout the world. So, the term ICT is a widely spread phenomenon in teaching and learning these days. It has made a significant contribution in ELT.

It can be inferred that technology is an everincreasing part of the English language classroom. It can easily be used either in language class or outside. It has become a very useful instrument for both personal and professional lives of people. Kayser, McKenzie, Russell, and Sorin (2009) state "Technology is becoming increasingly important in both our personal and professional lives and the learners of English are using technology more and more. Therefore, the problem how to teach English with technologies is very actual for every teacher nowadays" (pp. 5-9).

In addition, Fominykh (n. d.) opines that as a teacher of English he tries to bring computers, technology and the Internet to his classes and he finds a lot of advantages of using ICT in teaching English. As for grammar, the increase in the number of interactive exercises on CDROM and the web has undoubtedly benefited learners. Students can practice 24 hours a day, 7 days a week and receive instant feedback.
Thus, ICT is a double-edged sword which has proven to be a valuable aid to solving problems and accomplishing tasks in education, and many other human endeavors. It has become a very important part of the educational delivery and management processes. It plays a crucial role in the process of teaching and learning because these involve information-handling. Evidently, no one would deny its contributions to the educational field, specially, to the teaching and learning of English language. It has considerable influence on the way we teach and the content we deliver. To its better utilization we should ask ourselves about its availability and its affordability concerning its cost in developing countries like Nepal.

\section{Digital divide in Nepalese ELT}

Digital divide is a gap between the underprivileged members of society, especially the poor, rural, elderly, and handicapped portion of the population who do not have access to computers or the internet and the wealthy, middle-class, and young living in urban and suburban areas who have access. Regarding digital divide in ELT, it is worth quoting Harmer (2002, p. 175, as cited in Karn, 2011, p. 64) who states that:

If you walk into some classrooms around the world, you will see fixed data projectors, interactive whiteboards (IWBs), built- in speakers for audio material that is delivered directly from a computer hard disk, and computers with round-the-clock internet access. Whenever teachers want their students to find anything out, they can get them to use a search engine like Google and the result can be shown to the whole class on the IWB.

The classroom situation mentioned above by Harmer is beyond imagination for many 
schools in Nepal, where some teachers teach with chalk and duster, others deliver their sermons in the field basking their body in the sun (Karn, 2011, p. 64). This suggests that our classrooms are not quite different from Gurukul tradition of education. This is because of the digital divide especially in education and to the social lives in general.

Regarding a huge digital divide throughout the country, the government of Nepal has initiated a number of efforts ahead. The establishment of Computer Association of Nepal (CAN) in 1992 and Internet User Group in 1997 is the most notable effort. Ministry of Education Nepal (2067) has also started to launch the advanced guru planning such as, Interactive Digital Content Development (IDCD), ICT Human Resource Development (ICTHRD), ICT Infrastructure Development (ICTID) and Internet Connectivity to the Schools (ICS). The obstacle, however, is by no means insurmountable if broken down into specific tasks that must be accomplished.

\section{Impact of ICT on ELT}

Teachers of English around the world prefer the communicative teaching and learning methods, rather than the traditional chalk and talk method. The chalk and talk method dominates the student-centered approach and neglects the students' communicative skills. The teacher-dominated approaches like discussion and lecturing depended mainly on the learners' memory (rote learning) and did not concern about the authentic use of language. To overcome these circumstances, language teachers started to integrate technology in teaching. Since then, ICTs have changed the pace of teaching strategies to meet the goals of his/her materials and the needs of his/her students. On the other hand ICTs have given students many opportunities to practice English in and out of the classroom. ICT can be used to integrate the language skills such as listening, speaking, reading and writing. It increases the efficiency of the system and makes teachers and students more autonomous in teaching learning process. Ibrahim (2010, p. 212) talks about the impact of ICT as:

The ICTs put forward an influential base for efficient education. Now, we need the modern technologies for a better blended method of delivery to create apt teaching techniques to enhance the process of learning English language. ICTs are very motivating because they help the learners to learn the language which is carefully designed to meet the prescribed goals.

In the present day world, ICT can be a very effective means in supporting informationhandling and therefore assisting in carrying out better ELT classroom activities. It is a well-known fact that not a single teacher is capable of giving up-to-date and complete information in his/her subject. The ICT can fill this gap because it can provide access to different sources of information and to information-handling tools. ICT provides variety in the presentation of content. It helps learners in concentration, better understanding, and long retention of information which is not possible otherwise. Similarly, it provides flexibility through information-handling tools to a learner which is denied by the traditional banking method. The nice thing it provides is online interaction facility around the world where students and teachers can exchange their ideas and views, and get clarification on any topic from different experts, practitioners.

In addition to this, regarding the positive impact of ICT in ELT, it is worth quoting Hennessy et al. (2010) who claim:

Bringing ICT into the classroom can have a considerable impact on the practice of teachers when ICT is conceptualised as a tool that supports a 
real change in the pedagogical approach. Not only do the teachers need to change their roles and class organisation, they also need to invest energy in themselves and their students in preparing, introducing and managing new learning arrangements (pp. 45-46).

In conclusion, ICTs have invaluable positive impacts in ELT. They facilitate the teaching learning process having better outcomes on a practical basis. To achieve this, the teachers who use ICTs in their classrooms have to demonstrate high level of enthusiasm and hard work along with the collaboration at utmost level.

\section{Commonly used ICT/Web tools in ELT}

ICT and Web tools have been integrated as potentially powerful information-handling tools for educational change and reform. Different kinds of ICTs which include radio and television, as well as latest digital technologies such as computers and the internet are widely used in the $21^{\text {st }}$ century ELT classroom. The appropriate use of the ICT and web tools can be beneficial to strengthen the relevance of ELT to the increasingly digital workplace and to have better outcomes in teaching learning environment. They can also raise the quality of teaching learning activities making it engaging relating to real life experience. Highlighting the common use of ICT and Web tools in ELT classroom, UNDP (2003) states:

In recent years there has been a groundswell of interest in how computers and the Internet can best be harnessed to improve the efficiency and effectiveness of education at all levels and in both formal and nonformal settings. But ICTs are more than just these technologies; older technologies such as the telephone, radio and television, although now given less attention, have a longer and richer history as instructional tools.

The selection and use of ICT / Web tools in ELT class depends on different factors such as class size, classroom management, electronic literacy of the teachers and students, subject area, availability of the tools, etc. Considering these factors, the common types of ICT/Web tools used in ELT in the present day world are as follows:

Laptop: Laptop is a portable and a mini personal computer which is widely used because of its battery backup nature. Teachers as well as their students can use it to note down important information about their lessons.

Digital Recording: It is a useful tool in foreign language classrooms where a primary goal is for students to practice speaking the target language, hear how they sound, and improve their speaking proficiency.

Mobile Gadget: It is used to make a photo documentary using the camera function. And the teacher can assign a theme for the documentary to their students. Similarly, students can use the applications available in it. For example, instead of taking out a dictionary, students can simply use their translator, and instead of trawling through books for a piece of literature, they can search on Google and be directed to a specific word.

Multimedia Projector: Multimedia projectors are used frequently in classrooms for multimedia presentations. The teacher can use it to display his/her lesson along with audio visual features on the white board while instructing students.

Interactive White Board: Interactive whiteboards are good replacements for traditional whiteboards or flipcharts as they provide ways to show students everything 
which can be presented on a computer's desktop. Chhabra (2012) says, "Interactive white board helps teachers use a studentcentered approach to teach language and they can use SMART Boards to improve reading comprehension, and teach grammar and writing".

Internet: Internet can be used as a medium of language learning through email, WWW (World Wide Web), text, audio and video conferencing. Internet is not merely a source of authentic material in English but also a source of information in the form of articles, courses, conferences.

Facebook: It has heavily influenced the world today and ELT has no exception to it. Mostly, students can get benefits from the Facebook-groups and pages where students as well as teachers can post and share the course-related information like assignments, outlines, and other materials.

YouTube: YouTube surfing can be very much effective for various aspects of English as to enhance language aspects such as vocabulary, accents, pronunciations, voice modulation and many more. Chhabra (2012) argues that the real advantage of using YouTube in teaching English is that it offers authentic examples of everyday English used by everyday people'. The teacher can use it as a tool for improving their listening and speaking, reading and writing skills.

Weblog: Basically in blog visitors can read the post, comment on it or link to it or email to anyone they like. Blogging provides the bloggers and readers with the updated information and best practices in the pedagogy basing on true experience, knowledge and research findings.

Twitter: As an online education technology tool, the impact of it in teaching learning activities is limitless. The teacher can tweet a single word or an idea about his language lessons and can collect his students' viewpoints and analyze their potential. It can be done with the students of the same classroom or the students of the different classrooms on the class twitter network.

Thus, along with the above mentioned information-handling tools, the other technological devices (iPod, smart phone, smart board, etc.), skype, email, wiki, etc. can also be used in ELT to have better outcomes.

\section{Current practice of ICT/Web tools in Nepalese ELT context}

The Nepalese Government approach to importance of ICT in education during the last ten years has been changing depending on the changes of governments. The government has made a commitment and has passed the 'National Informatics Law $2067^{\prime}$ to launch the e-governance in the country. It is to support computer literacy of citizens and to adopt digital technology in education which is a positive beginning to the launching of technology-facilitated or e-class pedagogy in teaching. 'Open Learning Exchange, and E Paath (OLE Nepal)' is an example of an endeavour that the government made for the integration of ICT in ELT. Nepal: E-Pustakalaya is an electronic library, a repository of reference material for the students, consisting of full text documents, images, audio, video clips and software that are relevant for students. E-Pustakalaya deploys a simple child friendly learning environment that allows children to navigate, search, and link different documents including reference materials, course-related content, magazine, and newspaper content. Moreover, students can download the content material as well as read it online. The repository is accessible on the Internet to other users at http:/ / www.pustakalaya.org.

Likewise, Ministry of Education (MoE) is encouraging the use of integrated 
educational technologies and this is filtering into the English language classroom in most parts of Nepal. Similarly, we can see that some of the well-facilitated government-aided and private schools are integrating 'Midas e-Learning' in primary and lower secondary level which is one of the significant steps of bringing new technologies in instructing students in language learning activities. The e-learning tools like Internet, YouTube, Skype, Twitter, Blogs, Mobile phones, Interactive Boards and many more have added not only stimulus but also learners' engagement and true collaboration and interaction among teachers and students in their day to day language learning activities. With the help of these tools, teachers can engage learners to become skilled at English language by using the innovative ELT techniques like English songs, movie clippings, dramatics, advertisements, sports commentaries and many more.

A point to be noted however, is that in the name of digitization, the schools and colleges have recently been installing a couple of digital e-learning tools that comprise communication devices or applications consisting of radio; television as well as newer digital technologies such as computers, multimedia projector, audio equipment, mobile phones, interactive whiteboards, printers, and also integrating web tools like blogs, Facebook, the Internet, e-mails, video conferencing and many more. All this is to assist better and increasingly complex informationhandling. This is, of course, a good sign, and a very good positive step; however, we cannot be and must not be satisfied with it. Every ELT culture throughout the country should be equipped with at least a couple of laptops, multimedia projectors, networked computer and a printer so that ELT activities can better be carried out with the notion of student-centeredness.

\section{Methods and procedures of the study}

\section{Design of the study}

This research work is a field-based crosssectional survey research. A survey usually relies on large-scale data gathered from a wide population in order to enable generalizations to be made about given factors or variables. According to Cohen et al. (2010), "A survey has several characteristics and several claimed attractions; typically it is used to scan a wide field of issues, populations, programmes etc. in order to measure or describe any generalized features" (p. 206).

Thus, the main purpose of carrying out this survey research is to obtain a snapshot of condition, attitudes and or events at a single point in time on ICT and Web tools in ELT in Nepalese private secondary and higher secondary education.

\section{Population and sample of the study}

The population of this study was the secondary and higher secondary level English teachers teaching in private schools of Kathmandu valley. The sample size was 40. The primary data were collected from three districts of Kathmandu valley in proportionate way based on the geographical area and population of the districts as well as the schools integrating ICT in English language teaching. This fact allowed the researcher to take this group of teachers as a significant sample to obtain objective and reliable data.

\section{Sampling procedures}

The non-random purposive sampling procedure was used while selecting the schools. Twenty English teachers from Secondary Schools and the equal number from Higher Secondary Schools were selected purposively. The sample was taken considering the geographical area and 
population of the districts and much consideration was given to the ICT-integrated schools in ELT while selecting the informants. Kathmandu is the largest district of the valley so, 8 Secondary and the equal number of Higher Secondary English teachers were selected. The case is similar to Lalitpur districts as in Kathmandu because of the availability of ICTintegrated schools. Similarly, 4 Secondary and the equal number of Higher Secondary English teachers were selected from Bhaktapur. Altogether, 40 English teachers were selected from 26 schools.

\section{Data collection tools}

The main tool for the collection of data was a set of questionnaire. The survey questionnaire consisted of 9 close-ended and 5 open-ended questions and a contingency question was used which can be seen at the appendix section of the present study.

\section{Data analysis and interpretation procedures}

Analysis and interpretation of the collected data is considered as a crucial stage while carrying out research whether it is qualitative or quantitative. Still, there is not a single way to analyse and interpret the data. The collected data in this study were analysed and interpreted qualitatively and quantitatively as well.

\section{Results}

On the basis of the rigorous analysis and interpretation of the data, the following results were extracted.

\section{ICT/Web tools in ELT}

ICT usage, understood as informationhandling, has many positive impacts on teaching learning activities, i.e. almost all the teachers considered that ICT usage has positive impact during the English language lesson.

a. The integration of ICT/Web tools enhances teaching and learning creating a learner-centred atmosphere, updating teachers with the recent innovation in ELT, making them autonomous, creating varieties and making ELT more practical and goal oriented.

b. The use of ICTs/Web tools create motivation and communicative teaching in ELT, i.e. all the participants representing secondary level and the equal number from higher secondary level preferred motivation as the first task of performance and $90 \%$ of the secondary English teachers and 95\% of the higher secondary English teachers preferred communicative teaching as the second task of performance.

The primary data collected from 20 secondary English teachers and the equal number of higher secondary English teachers from three districts of Kathmandu Valley in proportionate way based on the geographical area and number of population of the districts as well as the schools using ICT/Web tools in English Language Teaching were analyzed and interpreted descriptively as well as statistically. Thus the collected data were analyzed and interpreted descriptively as well as statistically arranging them into the following six thematic grounds/ dimensions to meet the objectives of the study.

- Teachers' characteristic

- ICT/Web tools in ELT

- ICT-Based activities in ELT

- Uses of ICT/Web tools in ELT 
- Teachers' experiences of using ICT/ Web tools in ELT

- Possible ways for successful integration of ICT/Web tools in ELT

This article only mentions the second thematic ground and the analysis and interpretation of the data based on it, which is presented as follows:

\section{ICT/Web tools in ELT}

The core concern of the research study lies on this section. The central concern of this thematic ground is to find out what importance does the ICT/Web Tools have in ELT in Nepalese private secondary and higher secondary level.

Regarding the importance of ICT/Web tools in ELT, the information obtained from the respondents were analysed in terms of the criteria mentioned below which are directly linked to the objective of the study'To find out the uses of such ICT/Web Tools in carrying out better ELT classroom activities.'

\section{Impact of ICT/Web tools on ELT}

To find out the impact of ICT/ Web tools on English language teaching, teachers were asked a close-ended question; "Do you consider ICT use during lessons has positive impact on the following? Please select the option that applies to you." The information regarding this is presented in Table no. 1 .

Based on the information presented in the above table, it can be seen that the majority of the secondary level English teachers i.e. $75 \%$ and the equal number of the higher secondary level English teacher responded that students concentrate a lot while teaching. Similarly, $40 \%$ of the secondary level English teachers and $50 \%$ of the higher secondary level claimed that students somewhat feel more autonomous in learning.

In terms of the impact no. 4, 50\% of the secondary level English teachers and the equal number of the higher secondary level English teachers responded that ICT facilitates collaborative work between students significantly. Likewise, $45 \%$ of the secondary level English teachers and majority of the higher secondary level English teachers replied that ICT improves the class climate a lot. Along with these responses, some of the teachers also responded that the other positive impacts like ICT usage help students to form a better concept of abstract ideas a lot.
Table No. 1 Impact of ICT/Web Tools in ELT

\begin{tabular}{|c|c|c|c|c|c|c|c|c|c|c|c|c|c|c|c|c|c|}
\hline \multirow{3}{*}{ 妄 } & \multirow{3}{*}{ Impact } & \multicolumn{8}{|c|}{ Secondary } & \multicolumn{8}{|c|}{ H igh er Second ary } \\
\hline & & \multicolumn{2}{|c|}{ A lot } & \multicolumn{2}{|c|}{$\begin{array}{l}\text { Some } \\
\text { what }\end{array}$} & \multicolumn{2}{|c|}{$\underset{\text { little }}{\text { A }}$} & \multicolumn{2}{|c|}{$\begin{array}{c}\text { Not } \\
\text { at } \\
\text { all }\end{array}$} & \multicolumn{2}{|c|}{ A lot } & \multicolumn{2}{|c|}{$\begin{array}{l}\text { Some } \\
\text { what }\end{array}$} & \multicolumn{2}{|c|}{$\underset{\text { little }}{\text { A }}$} & \multicolumn{2}{|c|}{$\begin{array}{c}\text { Not at } \\
\text { all }\end{array}$} \\
\hline & & $\dot{z}$ & 8 & $\dot{\mathbf{z}}$ & $\therefore$ & $\dot{z}$ & $\therefore$ & $\dot{z}$ & $\therefore$ & $\dot{z}$ & $\therefore$ & $\dot{z}$ & 5 & $\dot{\mathrm{z}}$ & $5^{\circ}$ & $\dot{\mathbf{z}}$ & 8 \\
\hline 1 & $\begin{array}{l}\text { Students } \\
\text { concentrate } \\
\text { more on } \\
\text { their } \\
\text { learning }\end{array}$ & 15 & 75 & 3 & 15 & 2 & 10 & - & - & 15 & 75 & 3 & 15 & 2 & 10 & - & - \\
\hline 2 & $\begin{array}{l}\text { Students } \\
\text { feel more } \\
\text { autonom ou } \\
\text { s in their } \\
\text { learning }\end{array}$ & 6 & 30 & 8 & 40 & 6 & 30 & - & - & 6 & 30 & 10 & 50 & 3 & 15 & 1 & 5 \\
\hline 3 & $\begin{array}{l}\text { Students } \\
\text { understand } \\
\text { more easily } \\
\text { what they } \\
\text { learn }\end{array}$ & 10 & 50 & 10 & 50 & - & - & - & - & 10 & 50 & 8 & 40 & 2 & 10 & - & - \\
\hline 4 & $\begin{array}{l}\text { ICT } \\
\text { fa cilita tes } \\
\text { collaborati } \\
\text { ve w ork } \\
\text { between } \\
\text { students }\end{array}$ & 10 & 50 & 9 & 45 & 1 & 5 & - & - & 7 & 35 & 10 & 50 & 3 & 15 & - & $\cdot$ \\
\hline 5 & $\begin{array}{l}\text { IC T } \\
\text { im proves } \\
\text { the class } \\
\text { clim ate }\end{array}$ & 9 & 45 & 9 & 45 & 2 & 10 & - & - & 15 & 75 & 5 & 25 & - & - & - & - \\
\hline 6 & Others & & & & & & & & & & & & & & & & \\
\hline
\end{tabular}


In short, it can be concluded that ICT usage has many positive impacts on teaching learning activities.

\section{Integration of ICT/Web tools}

In order to elicit information about the enhancement in English Language Teaching by the integration of ICT/Web tools, teachers were asked an open-ended question; "How does the integration of ICT/Web tools in ELT enhance teaching learning? Could you please mention any three based on your own experience?"

Among 40 English teachers from secondary and higher secondary level, 38 (94\%) of them mentioned the changes brought by the use of ICT/Web tools in English language teaching in their classroom. The responses made by the teachers on the question are listed below:

a. It helped teachers to be up-to-date with the recent innovation and new trends of teaching.

b. Integration of ICT/Web tools in ELT made classroom teaching more practical and sustainable.

c. It helped students and teachers collaborate and interact with each other.

d. Use of ICT created student-centred teaching.

e. Students' creativity, logical power and critical thinking were empowered.

f. Learners and the teachers became autonomous in their profession.

g. It generated motivation, enthusiasm, readiness and avoided monotony in teaching learning activities.

In short, it can be inferred that the integration of ICT/Web tools can enhance teaching and learning creating learnercentred atmosphere.
Teachers' personal story of using ICT/ Web tools in ELT

In order to find out the teachers' practical usage of ICT/Web tools in English language teaching, the respondents were asked an open ended question, "Could you please share one case/experience/personal story of using ICT/Web tools in ELT classroom?". Some of the samples of the respondents' personal story of using ICT/Web tools are presented in the following manner:

Firstly, a Secondary English teacher with M.A in English Literature having more than 11 years of teaching experience and above 5 years of experience in using ICT/Web tools in ELT responded that:

"Once I had difficulty explaining a story based on dual-existence. The concept was not clear to my students. After reaching home, I went on surfing net. There I found a movie on YouTube. I decided to show the movie to my students. The movie helped to make the concept of dual-existence clear without any stress."

To sum up, the use of ICT/Web tools help teachers to carry out effective classroom activities. They have become the integral part of language teaching which make teachers resourceful and their content delivery very effective.

\section{Conclusion and implications}

As the study was set out to investigate what ICT/Web tools are used and to what extent the English language teachers at private secondary and higher secondary schools of Kathmandu Valley engage in using such tools in teaching, it was found that:

a. Majority of the teachers found ICT/Web tools very useful to carry out effective classroom activities. The ICT tools 
(mobile phone, laptop, multimedia projector) and Web tools (YouTube, facebook, wiki, email, blog) were used in their teaching learning context.

b. Almost all the secondary and higher secondary English teachers involved in ICT-based activities in teaching English.However some teachers did not have any idea about such activities. It could be seen that the ICT-integrated classroom activities were effective and product oriented.

c. ICT usage has many positive impacts in teaching learning activities. The integration of ICT/Web tools enhance teaching and learning creating learnercentred atmosphere, updating teachers with the recent innovation in ELT, making them autonomous, creating varieties and making ELT more practical and goal oriented.

Thus, the results of the study clearly suggest the need for integrating ICT/Web tools to have better outcomes in English langue teaching. And the integration of ICT/Web tools in ELT enhances teaching and learning creating learner-centred atmosphere that allows learners to learn things in their own pace. Similarly, it is noteworthy that they function as support for foreign language teachers who intend to make classroom teaching effective as well as autonomous and making learners responsible for their own learning. Finally, this study further provides some insights that the growing use of technology in ELT can better be promoted in Nepal in near future that can help lessen the current digital divide as well.

\section{About the Author}

Chandra Prasad Acharya holds master's degree in ELT from Tribhuban University Kirtipur, Kathmandu. He is a life member of NELTA. Acharya has also presented papers at various ELT conferences. He has been associated with English Language Teaching (ELT)for half a decade. His areas of interest include technology in ELT and critical pedagogy.

\section{References}

Ajit, T. J. (n. d.). Use of ICT for effective teaching and learning [PowerPoint slides]. Thiruvananthapuram, India: Institute for Pedagogic Informatics.

Awasthi, J. R. (2003). Teacher education with special reference to English language teaching in Nepal. Journal of NELTA, 8, 17-28.

Chhabra, P. (2012). Use of E-Learning tools in teaching English. International Journal of Computing \& Business Research. ISSN (Online): 2229-6166.

Cohen, L., Manion, L. \& Morrison, K. (2010). Research methods in education. London: Routledge.

Fominykh. N. (n. d). Using ICT in teaching and studying English. Retrieved on $15^{\text {th }}$ April, 2013from http:// s h vid k o 172 . n a r o d 2.ru / ICT_in_Teaching_English.doc

Hennessy, S., Harrison, D., \& Wamakote, L. (2010). Teacher factors influencing classroom use of ICT in Sub-Saharan Africa. Itupale Online Journal of African Studies, 2, 39-54. Retrieved on $10^{\text {th }}$ April 2013 from http:// www.cambridgetoafrica.org / resources/hennessy\%20etal_final.pdf

Ibrahim, A. M. (2010). Information \& communication technologies in ELT. Journal of Language Teaching and Research, 1(3), 211-214. doi:10.4304/jltr.1.3.211214

Karn, S. (2011). Wounded warrior rescuing Thakur Ram from deadly epidemic. A Multidisciplinary Journal, 1(1). 
Kayser, A. McKenzie, C., Russell, M. \& Sorin, R.(2009).Creating Meaningful Web Pages: A Project-Based Course / Amy Kayser. Retrieved on 20th April, 2013 from http://www.ido.rudn.ru/ nfpk/ikt/vved.html. (21.07.09)

Newa, D. R. (2007). Teacher effectiveness in relation to work satisfaction, media utilization and attitude towards the use of information and communication technology among secondary school teachers of Nepal. An unpublished Ph. D. dissertation. Panjab University Chandigarh, India.

Pradhan, J. (2002). Information technology in Nepal: What Role for the Government? The Electronic Journal on Information Systems in Developing Countries, 8(3), 111. Retrieved on $21^{\text {th }}$ May, 2013 from http:/ / www.ejisdc.org / ojs 2/ index.php/ejisdc/article/viewFile/42/ 42

Suwannasom, T. (2010). Teacher Cognition About Technology-Mediated EFL Instruction in the Thai Tertiary Context. An unpublished $\mathrm{Ph}$. D thesis, Massey University, New Zealand.

Taylor, M., C. (2001). The Moment of Complexity: Emerging Network Culture. Chicago: The University of Chicago Press.

UNDP. (2003). Kenya Human Development Report: Participatory Governance for Human Development (UNDP). Journal of Language Teaching and Research, 1(3), 211214.

Warschauer, M. (1996). Computer Assisted Language Learning: an Introduction. In Fotos S. (ed.) Multimedia language teaching (pp. 3-20). Tokyo: Logos International.

\section{Appendix-I}

\section{Questionnaire}

Dear Sir/Madam

I am Chandra Prasad Acharya, an M. Ed. student at the Department of English Education, Tribhuvan University, Kirtipur, Kathmandu, Nepal. This survey questionnaire has been designed to collect teachers' perspectives about Information Communication Technology(ICT) and Web Tools in ELT, especially in secondary and higher secondary education of Nepal. This questionnaire has been prepared in order to accomplish a research work entitled "Use of ICT and Web Tools in ELT in Nepal" for the thesis of M. Ed. in Education in English as a requirement of the course 'Thesis Writing' (Eng. Ed. 598) - instructed by Dr. Anjana Bhattarai, Head of the Department. The research is being carried out under the supervision of Dr. Tara Datta Bhatta, Professor, at the Department. Your cooperation in responding the questionnaire and your responses will have great value in accomplishing my research. I appreciate your honest opinion and assure you that your responses will be completely anonymous. I promise that strict confidentiality will be maintained in my study ahead.

Thank you for your patience and cooperation in advance.

Researcher

Chandra Prasad Acharya

Department of English Education

University Campus Kirtipur

Kathmandu

Name:

Institute:

Address:

Qualification/Specialization: 
1. Are you teaching as a secondary or higher secondary teacher?

Secondary

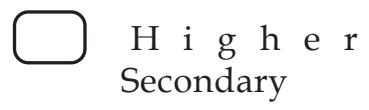

2. How would you describe your current employment status?

$\square$ Full time $\square$ Part time

3. How many years have you been working in ELT?

$\square$ Less than a year

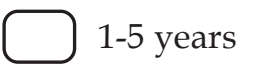

$\square$ 6-10 years

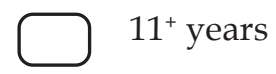

4. How long have you been using ICT/ Web Tools for your ELT classroom?



Less than a year
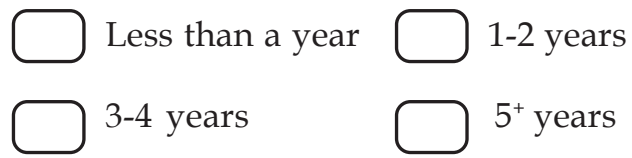

3-4 years



5. Do you have any Technology Department/ICT Unit at your school?
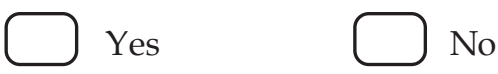

If the response is ' $\mathrm{No}^{\prime}$, have your ever talked to the authority to launch it?
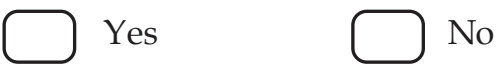

6. Which of the following technologies get used in your classroom teaching? Please select all the options that apply to you. (Social networking site: facebook, twitter, wiki, YouTube, etc.)

$\square$ Laptop

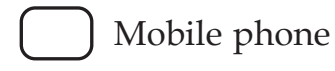

Networked computer D i g i t a 1

video recording

Multimedia projector

Interactive whiteboard
Social networking site; please specify

Other (Please specify)

7. How often do you use the following ICT/ Web Tools in teaching learning? Please select the option that applies to you.

\begin{tabular}{|c|c|c|c|c|}
\hline & $\begin{array}{l}\overline{0} \\
\overrightarrow{0} \\
z\end{array}$ & 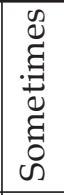 &  & $\begin{array}{l}\overrightarrow{0} \\
\overrightarrow{0} \\
\overrightarrow{0} \\
\overrightarrow{0} \\
\text { | }\end{array}$ \\
\hline $\begin{array}{l}\text { Material creation tools } \\
\text { (e.g. Wordle, Quizlet) }\end{array}$ & & & & \\
\hline $\begin{array}{l}\text { Voice recording tools } \\
\text { (e.g. Voxopop) }\end{array}$ & & & & \\
\hline $\begin{array}{l}\text { Audio editing tools } \\
\text { (e.g. Audacity) }\end{array}$ & & & & \\
\hline $\begin{array}{l}\text { Social networking tools } \\
\text { (e.g. Facebook, Twitter) }\end{array}$ & & & & \\
\hline $\begin{array}{l}\text { Integration tools(e.g. } \\
\text { Wiki) }\end{array}$ & & & & \\
\hline $\begin{array}{l}\text { Video sharing sites(e.g. } \\
\text { YouTube) }\end{array}$ & & & & \\
\hline $\begin{array}{l}\text { Online notetaking(e.g. } \\
\text { Evernote) }\end{array}$ & & & & \\
\hline
\end{tabular}

If any, Please specify and state frequency-

8. How useful have you found the following applications of technology as part of your classroom teaching? Please select that applies to you. 


\begin{tabular}{|c|c|c|c|c|}
\hline & 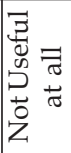 & 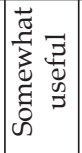 & 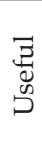 & 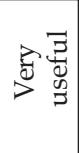 \\
\hline PowerPoint presentations & & & & \\
\hline $\begin{array}{l}\text { Using MS Office (Word, Excel, } \\
\text { Access, etc) applications }\end{array}$ & & & & \\
\hline $\begin{array}{l}\text { Using Internet to find } \\
\text { information }\end{array}$ & & & & \\
\hline $\begin{array}{l}\text { Accessing information from } \\
\text { CD/DVDROMs }\end{array}$ & & & & \\
\hline $\begin{array}{l}\text { Downloading lecture notes and } \\
\text { essential information }\end{array}$ & & & & \\
\hline Using self-assessment tests & & & & \\
\hline $\begin{array}{l}\text { If any other, please specify and } \\
\text { state frequency- }\end{array}$ & & & & \\
\hline
\end{tabular}

9. Which of the following activities do you carry out using ICT/Web Tools in your classroom teaching? (Please select as many as you are experienced with)



Use computer programmes (e.g. PowerPoint) to prepare teaching materials/exercises/ tasks for students

Use e-mail or web discussion to communicate with students

Use social networking sites to communicate with students

Post homework for students on the school website

Use or download online materials as learning and teaching resources Create a weblog or website for students to share their activities

Other (Please specify)

10. What activities do you carry out using ICT/Web Tools in your ELT classroom in order to enhance specific language skills?

\begin{tabular}{|l|l|}
\hline Lg. Skills & Activities \\
\hline Listening & \\
\hline Speaking & \\
\hline Reading & \\
\hline Writing & \\
\hline
\end{tabular}

11. Do you consider ICT use during lessons has a positive impact on the following? Please select the option that applies to you.

\begin{tabular}{|l|l|l|l|l|}
\hline & $\begin{array}{c}\text { Not at } \\
\text { all }\end{array}$ & A little & Somewhat & A lot \\
\hline $\begin{array}{l}\text { S t } \mathrm{u} \mathrm{d} \mathrm{e} \mathrm{n} \mathrm{s} \\
\text { concentrate more on } \\
\text { their learning }\end{array}$ & & & & \\
\hline $\begin{array}{l}\text { Students feel more } \\
\text { autonomous in their } \\
\text { learning }\end{array}$ & & & & \\
\hline $\begin{array}{l}\text { Students understand } \\
\text { more easily what } \\
\text { they learn }\end{array}$ & & & & \\
\hline $\begin{array}{l}\text { ICT facilitates } \\
\text { collaborative work } \\
\text { between students }\end{array}$ & & & & \\
\hline $\begin{array}{l}\text { ICT improves the } \\
\text { class climate (more } \\
\text { engaged \& less } \\
\text { disturbing) }\end{array}$ & & & & \\
\hline
\end{tabular}

If any other, Please specify and state frequency-

12. How does the integration of ICT/Web Tools in ELT enhance teaching learning? Could you please mention any three based on your own experience?

a.

b.

c.

13. In your opinion, the use of ICT/Web Tools in teaching generates: (Please select all that apply to you). 
Motivation

Operational efficiency

Readiness in learning

Communicative teaching

Work satisfaction

Collaborative learning

Other (Please specify)

14. Could you please share one case/ experience/personal story of using ICT/Web Tools in ELT classroom?

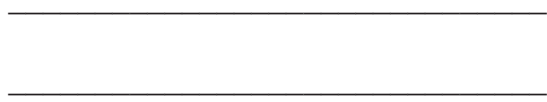

15. What changes have ICT/Web tools brought into your ELT class? Could you please mention the three most changes?

\begin{tabular}{|c|c|}
\hline $\begin{array}{c}\text { Before the use of ICT/ } \\
\text { Web tools }\end{array}$ & $\begin{array}{c}\text { After the use of ICT/Web } \\
\text { tools }\end{array}$ \\
\hline & \\
\hline & \\
\hline & \\
\hline
\end{tabular}

16. Could you please suggest any ways to successful integration of ICT/Web Tools in carrying out effective ELT activities?
Thank you for your patience and participation. Your responses are much appreciated.

\section{Appendix-II}

\section{List of Data Collected Schools}

\section{Private Secondary Schools from Kathmandu District}

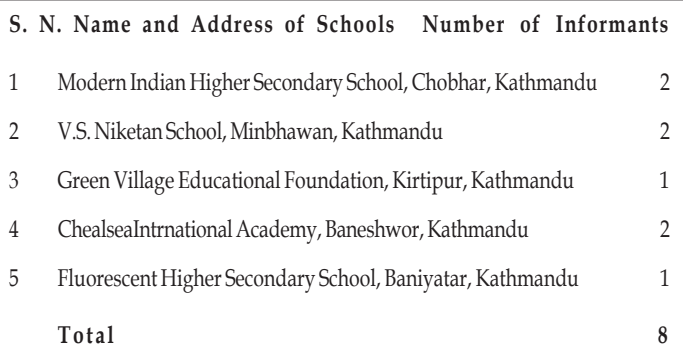

Private Higher Secondary Schools from Kathmandu District

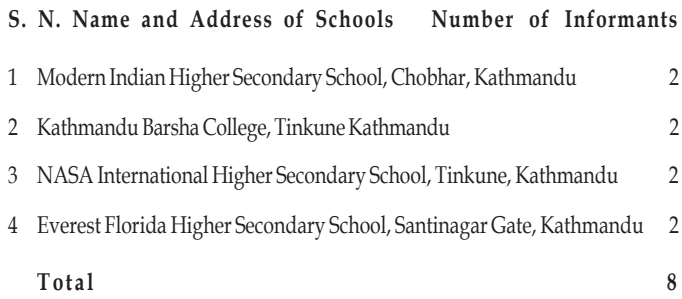

Private Secondary Schools from Lalitpur District

S. N. Name and Address of Schools Number of Informants

St. Xavier's School, Jawalakhel, Lalitpur

2 Little Angels Higher Secondary School Hattiban, Lalitpur

Ullens School, Khumaltar, Lalitpur

4 D.A.V.Sushil Kedia Vishwa Bharati Higher Secondary School,

Jawalakhel, Lalitpur

5 Rato Bangala School, Patan Dhoka

6. Greaded English Medium School, Dhapakhel, Lalitpur 
Private Higher Secondary Schools from Lalitpur District

\begin{tabular}{|cll|}
\hline S. N. & Name and Address of Schools & Number of Informants \\
\hline 1 & St. Xavier's School, Jawalakhel, Lalitpur & 1 \\
2 & Little Angels Higher Secondary School Hattiban, Lalitpur & 2 \\
3 & D.A.V.Sushil Kedia Vishwa Bharati Higher Secondary & \\
& School, Jawalakhel, Lalitpur & 3 \\
4 & Rato Bangala School, Patan Dhoka & 2 \\
\hline & Total & 8 \\
\hline
\end{tabular}

Private Secondary Schools from Bhaktapur District

\begin{tabular}{|lll|}
\hline S. N. & Name and Address of Schools & Number of Informants \\
\hline 1 & Springdale English Secondary Boarding School, & \\
& Katunje Height, Bhaktapur & 1 \\
2 & Gladstone Academy, Madhyapur Thimi-2, Mill Road, Bode, Bhaktapur & 1 \\
3 & Emmanuel Secondary Boarding School, Gathaghar, Bhaktapur & 1 \\
4 & Dibya Deep Jyoti English Secondary School, Lokanthali, Bhaktapur & 1 \\
\hline & Total & 4 \\
\hline
\end{tabular}

Private Higher Secondary Schools from Bhaktapur District

\begin{tabular}{|cll|}
\hline S. N. & Name and Address of Schools & Number of Informants \\
\hline 1 & SOS Hermann Minor HSS, Sano Thimi, Bhaktapur & 1 \\
2 & Mission International Academy, Suravinayak, Bhaktapur & 1 \\
3 & Araniko Higher Secondary School, Dhikoti, Bhaktapur & 2 \\
\hline & Total & 4 \\
\hline
\end{tabular}

